\title{
Pengembangan Model Pelukan HOTS Bagi Guru Sekolah Dasar
}

\author{
Hana Septina Kristanti ${ }^{1}$, Yari Dwikurnaningsih ${ }^{1}$, Wasitohadi ${ }^{1}$ \\ ${ }^{1}$ Manajemen Administrasi Pendidikan-Universitas Kristen Satya Wacana Salatiga
}

\section{INFO ARTIKEL}

Riwayat Artikel:

Diterima: $10-12-2020$

Disetujui: 21-12-2020

\section{Kata kunci:}

inductive training model; HOTS learning; primary school teachers; model pelatihan induktif; pembelajaran HOTS, guru sekolah dasar

\author{
Alamat Korespondensi: \\ Hana Septina Kristanti \\ Manajemen Administrasi Pendidikan \\ Universitas Kristen Satya Wacana Salatiga \\ Jalan Diponegoro 52-60 Salatiga \\ E-mail: kristantih86@gmail.com
}

\begin{abstract}
ABSTRAK
Abstract: This study aims to describe the existing HOTS learning training, its strengths and weaknesses, and to develop a HOTS learning inductive training model for elementary school teachers. This research method is R\&D. The research results reveal: (1) teacher training on HOTS so far has only focused on preparing HOTS questions, (2) training so far has not answered the needs of elementary school teachers both in terms of material and self-development. Strengths all primary schools, both public and private, have teacher representatives who have received training on HOTS topics, and (3) creation of HOTS Hugging Model for Elementary School Teachers who have advantages over existing training models. The conclusion is that the training model product falls into the very good criteria after being validated by 3 experts. The test results are in the good category.
\end{abstract}

\begin{abstract}
Abstrak: Penelitian ini bertujuan untuk mendeskripsikan pelatihan pembelajaran HOTS yang ada selama ini, kelemahan dan kelebihannya, serta mengembangkan model pelatihan induktif pembelajaran HOTS bagi guru SD. Metode penelitian ini adalah R\&D. Hasil penelitian mengungkap (1) pelatihan guru tentang HOTS selama ini hanya berfokus pada penyusunan soal HOTS, (2) pelatihan selama ini belum menjawab kebutuhan guru SD baik dari segi materi maupun segi pengembangan diri. Kelebihan, semua SD baik negeri maupun swasta, sudah ada perwakilan guru yang mendapatkan pelatihan dengan topik HOTS, (3) terciptanya Model Pelukan HOTS bagi guru SD yang memiliki keunggulan dibandingkan dengan model pelatihan yang sudah ada. Kesimpulan produk model pelatihan masuk pada kriteria sangat baik setelah divalidasi oleh tiga pakar. Hasil ujicoba produk pada kategori baik.
\end{abstract}

Kemdikbud melalui Ditjen GTK mengembangkan program pembelajaran berorientasi pada keterampilan berpikir tingkat tinggi atau Higher Order Thinking Skill (HOTS) dalam upaya peningkatan kualitas pembelajaran dan meningkatkan kualitas lulusan. Program ini dikembangkan mengikuti arah kebijakan Kementerian Pendidikan dan Kebudayaan yang pada tahun 2018 telah terintegrasi Penguatan Pendidikan Karakter dan pembelajaran berorientasi pada Keterampilan Berpikir Tingkat Tinggi (HOTS). Tuntutan kurikulum tersebut membawa konsekuensi diperlukannya pembelajaran yang merangsang peserta didik untuk memiliki keterampilan berpikir tingkat tinggi. Untuk mencapai hal tersebut, diperlukan guru yang memahami, mampu merancang, melaksanakan, dan mengevaluasi pembelajaran HOTS.

Pada kenyataannya, masih banyak pendidik yang belum memahami, mampu merancang, melaksanakan, dan mengevaluasi pembelajaran HOTS sesuai dengan pedoman yang ada. Hal tersebut menjadi masalah serius bagi pendidikan jika semua pihak tidak bergegas untuk menyelesaikan masalah tersebut. Hal tersebut tercermin dari hasil penelitian Rapih \& Sutaryadi (2018) dengan penelitiannya yang berjudul perspektif guru SD terhadap HOTS menunjukkan sebesar 79\% responden kesulitan dalam merancang dan menerapkan evaluasi berbasiskan HOTS, 59\% kesulitan dalam penyampaian materi pembelajaran, $45 \%$ kesulitan dalam merancang media pembelajaran, 38\% kesulitan dalam merancang perangkat pembelajaran dan sebesar $31 \%$ kesulitan dalam proses penyusunan bahan ajar. Febrianti (2017) menyatakan bahwa pendidik masih kesulitan dalam menyusun instrumen penilaian HOTS dalam proses evaluasi pembelajaran. Senada dengan Mailani (2018) yang hasil penelitiannya mengungkap masih banyak pendidik yang belum mampu merumuskan penilaian berbasis HOTS dalam proses penilaian. Sementara itu, Hanifah (2019) menyatakan bahwa para pendidik masih mengalami kesulitan dalam merumuskan indikator yang ada dalam HOTS menjadi instrumen penilaian. Selanjutnya, Faisal, Mailani, Ananda, \& Lova (2019) menyimpulkan rata-rata tingkat kompetensi guru dalam mengimplementasikan penilaian autentik berbasis HOTS di SD kota Medan adalah $74,81 \%$ pada kategori Cukup. 
Situasi tersebut, secara umum dihadapi sekolah di Kecamatan Sidomukti. Wawancara dengan Bapak Drs. Nur Purwono, M.Pd. selaku Korwil Kecamatan Sidomukti menyatakan bahwa selama ini kualitas soal evaluasi yang dibuat oleh para guru khususnya soal berorientasi HOTS masih kurang baik, jika dilihat dari karakteristik dan kaidah soal HOTS. Hasil supervisi juga menunjukkan penerapan pembelajaran HOTS belum sesuai yang diharapkan baik dari segi penyusunan RPP maupun pelaksanaan pembelajaran. Hasil studi pendahuluan melalui kajian dokumen dan hasil wawancara dapat disimpulkan bahwa pelatihan tentang pembelajaran HOTS di kota Salatiga sudah dilakukan meski tidak secara khusus. Itu pun, belum semua guru pernah mendapatkannya, hal ini disebabkan kuota peserta yang dibatasi. Diseminasi yang diharapkan tidak berjalan sesuai harapan sehingga masih banyak guru yang belum memahami dan mengimplementasikan pembelajaran HOTS sehingga berimbas pada hasil USBN yang menurun semenjak diintegrasikannya soal-soal HOTS. Penilaian HOTS tanpa pembelajaran HOTS akan menjadikan permasalahan di atas semakin sulit. Dengan demikian, diperlukan pelatihan bagi guru-guru SD untuk meningkatkan pemahaman hingga mampu membuat RPP pembelajaran HOTS. Selain itu, peserta pelatihan mendapatkan poin PKB untuk pengajuan PAK.

Penelitian Mikidadi (2013) The Effectiveness of Training of Government Primary School Teachers on Job Performance: The Case of Bukoba District Council menyimpulkan bahwa pelatihan sangat dibutuhkan lembaga layanan publik dengan trainer yang kompeten dan professional. Guru sebagai pelayan publik juga membutuhkan pelatih yang profesional secara berkelanjutan. Semua guru harus mampu mengakses pusat-pusat pelatihan yang sesuai dengan tugas pokok guru. Disamping itu, evaluasi dari pelatihan harus dilakukan secara tepat dan harus ada ketetapan yang realistis. Teacher training: technology helping to develop an innovative and reflective professional profile menyimpulkan bahwa program pelatihan guru harus berfokus pada pengembangan kompetensi guru. Untuk mewujudkan hal tersebut maka guru harus mematuhi semua etika dan standar profesionalisme yang telah diwajibkan kepada mereka guna bekerja secara individu maupun kolektif (Hepp et al., 2015). Philippine classroom teachers as researchers: teachers' perceptions, motivations, and challenges, hasil penelitiannya menyebutkan dukungan pembuat kebijakan dan organisasi pendidikan berupa workshop pelatihan guru merupakan kunci keberhasilan pengembangan profesionalime pendidik dalam menjalankan tugasnya di suatu negara (Ulla, Barrera, \& Acompanado, 2017).

Ketiga penelitian di atas mengungkap bahwa pelatihan sangat membantu guru dalam meningkatkan kompetensinya, sehingga guru dapat menjalankan tugas pokok dan fungsinya secara profesional. Dukungan dari berbagai pihak terkait untuk menjawab kebutuhan guru mengembangkan profesionalismenya sangat diharapkan. Dukungan tersebut berupa penyelenggaraan pelatihan yang berangkat dari analisis kebutuhan guru baik dari segi materi pelatihan dan kebutuhan akan pengembangan keprofesian berkelanjutan untuk keberlangsungan karirnya, dalam hal ini kenaikan pangkat. Berangkat dari latar belakang masalah yang ada maka sangat tepat jika peneliti mengembangkan model pelatihan untuk menjawab kebutuhan guru yang terkait dengan pembelajaran HOTS. Model pelatihan yang dikembangkan dirancang untuk dapat memenuhi kebutuhan guru baik dari segi materi untuk meningkatkan kompetensi guru terkait HOTS, namun juga memenuhi kebutuhan guru untuk kegiatan PKB guna pengajuan PAK.

Penelitian yang membahas tentang pengembangan model pelatihan untuk mengoptimalkan kompetensi guru telah dilaksanakan peneliti-peneliti sebelumnya. Antara lain penelitian yang dilakukan oleh (Hidayat \& Mariam, 2018) yang mengungkapkan melalui pelatihan induktif kemampuan guru SDN Wates dalam membuat proposal PTK meningkat. Sesuai prosedur pelatihan induktif, semua aspek pelatihan telah sesuai dengan kebutuhan peserta diklat sehingga dapat diterapkan untuk meningkatkan kemampuan membuat proposal PTK. Senada dengan itu, Kuncoro (2018) hasil penelitiannya menunjukkan bahwa terdapat pengaruh diklat induktif terhadap meningkatnya kinerja guru Penjasorkes di UPTD Pendidikan Kecamatan Ngaliyan dan Tugu Kota Semarang.

Penelitian yang dilakukan oleh Gunarso \& Sulasmono (2015) dengan penelitiannya yang berjudul Pengembangan Model Diklat Guru Sosiologi SMA tentang Pembelajaran Inkuiri Berbasis Budaya Lokal. Riyanti (2018) dengan penelitiannya yang berjudul Pengembangan Model Pelatihan Guru PPKn Berwawasan Pluralisme, keduanya sama-sama mengembangkan model pelatihan induktif sampai pada tahap kelima (Sugiyono, 2010) yakni tahap revisi desain setelah mendapat validasi ahli. Hasil dari kedua penelitian tersebut mengungkapkan keefektifan model pelatihan induktif dalam meningkatkan kompetensi guru. Model pelatihan yang dikembangkan dalam penelitian ini, hampir sejalan dengan yang dilakukan dengan keempat penelitian yang telah dibahas. Persamaan penelitian ini juga mengembangkan model pelatihan induktif. Perbedaan dengan penelitian Gunarso \& Sulasmono (2015); Riyanti (2018) adalah penelitian ini tidak hanya berhenti sampai pada tahap kelima, lebih jauh penelitian ini sampai pada tahap yang ketujuh Sugiyono yakni revisi produk setelah dilakukan ujicoba produk. Adapun yang membedakan dengan penelitian Hidayat \& Mariam (2018); Kuncoro (2018) adalah dari segi materinya yang dibahas dalam penelitian ini adalah pembelajaran HOTS.

Beberapa penelitian tentang HOTS yang pernah dilakukan, seperti penelitian Arnellis, Jamaan, \& Amalita (2019) yang berjudul Improving Teacher Professionalism Through in House Training Model to Higher Order Thinking Skills Items SMAN 10 Refference Padang menunjukkan bahwa guru-guru peserta IHT penyusunan soal HOTS di SMAN 10 Padang mampu memahami tingkatan taksonomi Bloom $(\mathrm{C} 4, \mathrm{C} 5, \mathrm{C} 6)$ dalam soal UN tahun 2018. Hal ini ditunjukkan dari rata-rata banyak guru yang benar mengubah soal HOTS yaitu $84 \%$. Hasil penilaian keaktifan peserta IHT dalam mengikuti kegiatan berada pada kategori baik dengan 61,33\%. Peneliti lain, Wardhana, Ariesta, \& Sarwono (2020) yang berjudul Pelatihan Penyusunan Soal Bahasa Indonesia Berorientasi HOTS untuk Guru SMP dan SMA mengungkapkan pelatihan yang dilaksanakan ternyata hasil 
yang sangat efektif. Ditunjukkan oleh perilaku subjek sebelum dan sesudah pelatihan Nilai yang terepresentasi pada saat pre test sebesar 46,63 lebih rendah jika dibandingkan dengan rata-rata nilai jawaban instrumen pada post test oleh subjek yaitu 72,60.

Penelitian Suhardiyanto \& Tijan (2019) yang berjudul Pendampingan Pengembangan Penilaian Pengetahuan Berbasis HOTS Bagi MGMP PPKN SMP di Kota Semarang menunjukkan dari segi penguasaan materi, terjadi peningkatan pemahaman terhadap penyusunan soal berbasis HOTS yaitu dari hasil tanya jawab yang dilakukan tim pengabdian pada awal kegiatan dan setelah dilaksanakannya kegiatan sebagian besar peserta pengabdian menyatakan ada peningkatan pemahaman dalam penyusunan penilaian pengetahuan berbasis HOTS. Penelitian Supriyadi, Rusilowati, Isnaeni, \& Winarsih (2019) yang berjudul Peningkatan Kemampuan Guru SD di Kecamatan Gajah Mungkur dalam Menyusun Soal HOTS. Setelah mengikuti pelatihan terjadi peningkatan pemahaman peserta mengenai perbedaan soal HOTS dan LOTS, ciri-ciri soal HOTS, serta cara penyusunan dan pengembangan soal HOTS sebesar 0,04 dengan kategori rendah. (Setiawan et al., 2019) melakukan penelitian yang berjudul Workshop Pengembangan Soal-Soal HOTS (High Order Thinking Skills) bagi MGMP IPA SMP Banyuwangi. Dalam pelaksanaannya, kegiatan Workshop bagi MGMP IPA SMP Banyuwangi ini terlaksana dengan baik dan efektif.

Samo \& Garak (2019) dengan judul penelitian Pelatihan Pengembangan Soal Geometri Level Higher-Order Thinking Skill (HOTS) Bagi Guru Sekolah Dasar di Kota Kupang, hasil yang diperoleh, yaitu (1) guru memiliki pemahaman yang sama tentang HOTS. Hasil pretest dan posttest menunjukkan adanya perubahan konsepsi tentang HOTS yang didefinisikan sebagai level berpikir analisis, kritis dan kreatif, (2) mampu mengembangkan keterampilan berpikir guru dalam menyusun instrumen soal level HOTS, dan (3) menumbuhkan komitmen mutu guru terhadap pengembangan kemampuan berpikir matematis siswa. Berdasarkan penelitian yang dilakukan sebelumnya mengenai HOTS, penelitian ini berbeda dengan penelitian yang dilakukan oleh sebagian besar peneliti terdahulu yakni yang dilakukan (Arnellis, Jamaan, \& Amalita, 2019; Samo \& Garak, 2019; Setiawan et al., 2019; Suhardiyanto \& Tijan, 2019; Supriyadi, Rusilowati, Isnaeni, \& Winarsih, 2019; Wardhana et al., 2020) yang hanya fokus pada evaluasi HOTS saja. Sehingga materi pelatihan hanya terfokus kepada pembuatan soal-soal HOTS. Namun, tidak dengan penelitian ini, peneliti mengembangkan model pelatihan pembelajaran HOTS yang lengkap mulai dari teori pengembangan RPP dan penilaian HOTS, rambu-rambu implementasi penyusunan RPP dan penilaian HOTS hingga praktik menyusun RPP HOTS. Santosa (2020) melakukan penelitian yang berjudul Improving Teacher's Ability to Make Lesson Plan Based on High Order Thinking Skills (HOTS) Through Group Guidance. Berdasarkan hasil penelitian dapat menyimpulkan bahwa kemampuan guru SMPN 2 Cerenti dalam menyusun RPP berbasis HOTS mengalami peningkatan melalui bimbingan kelompok.

Effendi \& Gunarto (2019) melakukan penelitian yang berjudul Pelatihan Pembelajaran dan Penilaian Berbasis HOTS (Higher Order Thingking Skill) bagi guru SD. Setelah kegiatan dilaksanakan beberapa manfaat yang diperoleh, yaitu (1) secara umum peserta yang hadir sangat antusias terhadap materi yang sampaikan, (2) peserta merasa mendapatkan ilmu yang baru berkaitan dengan pembelajaran dan penilaian berbasis HOTS. Zarkasi (2019) dengan judul penelitian Peningkatan Keterampilan Guru Dalam Penyusunan RPP Berbasis HOTS melalui Workshop dan Pembimbingan di SMA Negeri 8 Penajam Paser Utara. Penelitian tersebut menyimpulkan solusi melakukan bimbingan Kepala sekolah sebagai tindak lanjut workshop terbukti efektif karena pendekatan dialogis dan saling terbuka terjalin dalam proses bimbingan, di samping itu beberapa guru yang pernah menyusun PTK menduduki capaian sangat baik pada siklus I tiga orang dan meningkat menjadi enam orang, sedangkan peringkat baik dari sembilan orang meningkat menjadi 13 orang.

Penelitian ini hampir sejalan dengan yang dilakukan oleh (Effendi \& Gunarto, 2019; Santosa, 2020; Zarkasi, 2019). Adapun yang membedakannya adalah, model pelatihan yang disusun lebih detail, alokasi waktu dijelaskan lebih terperinci dengan pendekatan induktif. Terkait peserta pelatihan juga berbeda, sasaran pelatihan dalam penelitian ini adalah anggota KKG. Kegiatannya tidak hanya sebatas mendengarkan, namun diawali dengan memahamkan peserta tentang teori pengembangan RPP dan penilaian HOTS, rambu-rambu implementasi penyusunan RPP dan penilaian HOTS hingga praktik membuat RPP HOTS sehingga setelah pelatihan diharapkan guru membawa bekal baik secara teoritis mau pun praktis yang akan diimplementasikan di kelas masing-masing.

Hasil yang diharapkan dari model pelatihan yang dikembangkan paling tidak dapat sejalan dengan yang dilakukan oleh penelitian Alghamdi (2018) yang berjudul Faculty Professional Development and Its Impact on Teaching Strategies in Saudi Arabia, menyatakan sebanyak $89 \%$ peserta bersemangat untuk menerapkan pengetahuan dan skill untuk mengerjakan segala tugas dalam pelatihan HOTS. Selain itu, semua peserta pelatihan telah memahami konsep dasar HOTS dan mampu menerapkan secara mendalam dalam proses belajar mengajar di universitas. Lebih lanjut, hasil implementasi model pelatihan yang dikembangkan juga sejalan dengan penelitian Rahaju \& Fardah (2018) yang berjudul An Identification of Teachers'Ability on Posing HOTS Mathematics Problems, menyatakan bahwa melalui pelatihan HOTS sebanyak enam belas guru mampu menyusun soal HOTS, dan hanya satu guru yang masih belum mampu menyusun soal HOTS di akhir pelatihan.

Pembelajaran HOTS perlu disebarluaskan pada guru-guru SD melalui pelatihan yang tepat. Hal ini menjadi penting untuk dilakukan, karena berdasarkan hasil wawancara pelaksanaan pembelajaran yang dilakukan oleh guru SD kecamatan Sidomukti masih belum mengarahkan anak untuk berpikir tingkat tinggi. Oleh karena itu, perlu dikembangkan model pelatihan pembelajaran HOTS untuk meningkatkan pemahaman guru tentang teori pengembangan RPP dan penilaian HOTS, ramburambu implementasi penyusunan RPP dan penilaian HOTS hingga praktik membuat RPP HOTS sehingga setelah pelatihan diharapkan, guru membawa bekal baik secara teoritis maupun praktis yang akan diimplementasikan di kelas masing-masing. Penelitian ini bertujuan untuk (1) mendeskripsikan pelatihan pembelajaran HOTS yang selama ini diselenggarakan di 
kecamatan Sidomukti; (2) mendeskripsikan kelemahan dan kelebihan pelatihan pembelajaran HOTS yang selama ini diselenggarakan di Kecamatan Sidomukti; (3) mengembangkan model pelatihan induktif pembelajaran HOTS bagi guru SD.

\section{METODE}

Jenis penelitian ini adalah Research and Development (R\&D) atau penelitian pengembangan. Sugiyono (2010) menyatakan $\mathrm{R} \& \mathrm{D}$ adalah metode penelitian yang lazim digunakan untuk menghasilkan produk tertentu sekaligus menguji mangkus tidaknya produk tersebut. R \& D dalam penelitian ini digunakan untuk mengembangkan model pelatihan induktif pembelajaran HOTS. Penelitian pengembangan ini menggunakan rancangan penelitian model (Sugiyono, 2010) dengan mengambil sampai tujuh tahapan. Di mulai dari adanya masalah, pengumpulan data, desain produk, validasi desain, revisi desain, ujicoba produk, dan revisi produk. Subjek penelitian ini adalah guru Sekolah Dasar Kecamatan Sidomukti, Kota Salatiga, Provinsi Jawa Tengah. Waktu penelitian bulan Agustus-Oktober 2020. Subjek penelitian ini adalah guru Sekolah Dasar Kecamatan Sidomukti, Kota Salatiga, Provinsi Jawa Tengah. Waktu penelitian dari bulan Agustus-Oktober 2020. Teknik analisis data menggunakan mixed methods.

\section{HASIL}

Pelatihan pembelajaran HOTS yang selama ini diselenggarakan di kecamatan Sidomukti hanya berfokus pada penyusunan soal HOTS, baik untuk kepentingan PAS maupun Ujian Sekolah. Belum ada pelatihan yang secara utuh membahas tentang: Teori Pengembangan RPP dan Penilaian HOTS, Rambu-rambu Implementasi Penyusunan RPP dan Penilaian HOTS, Praktik Penyusunan RPP HOTS sehingga, guru masih merasa kesulitan mengimplementasikan pembelajaran HOTS di kelas meski tuntutan penilaian mereka sudah berorientasi HOTS. Kelemahan dalam pelatihan pembelajaran HOTS yang telah diselenggarakan di Kecamatan Sidomukti selama ini adalah (1) pelatihan berfokus pada penyusunan soal HOTS saja; (2) baik materi penyusunan soal HOTS, maupun pembelajaran HOTS hanya menjadi sub materi dari sebuah pelatihan; (3) kuota peserta terbatas; (4) peserta yang mewakili sekolah tidak menjalankan diseminasinya dengan baik; (5) alokasi waktu pelatihan terbatas; (6) struktur program pelatihan belum setara $30 \mathrm{JP}$ syarat minimal untuk mendapatkan poin pengembangan diri pada pengajuan PAK. Adapun kelebihan pelatihan HOTS yang telah terselenggara selama ini adalah (1) sudah ada pelatihan dengan topik HOTS, meski hanya menjadi sub materi dari sebuah pelatihan; (2) semua SD baik negeri maupun swasta, sudah ada perwakilan guru yang mendapatkan pelatihan dengan topik HOTS.

Model pelatihan induktif pembelajaran HOTS bagi guru SD yang dikembangkan berpedoman pada tahapan penelitian pengembangan yang dikembangkan Sugiyono (2010) yaitu (1) potensi dan masalah; (2) pengumpulan data; (3) desain produk; (4) validasi desain; (5) revisi desain; (6) ujicoba produk; (7) revisi produk. Dari tahapan tersebut tercipta produk model pelatihan yang menitikberatkan pada kebutuhan peserta pelatihan dengan nama "Model Pelukan HOTS bagi Guru SD" (Model Pelatihan Induktif Pembelajaran HOTS bagi Guru SD). Pendekatan yang digunakan dalam model induktif adalah menitikberatkan pada upaya pihak yang paling dekat, terkait langsung ke arah pihak yang lebih luas dan menyeluruh. Melalui pendekatan induktif ini, kemampuan yang telah dimiliki peserta pelatihan dibandingkan dengan kemampuan yang harus dimiliki sesuai dengan harapan yang dituntut dari diri peserta pelatihan. Berikut adalah langkah-langkah model pelatihan induktif (Kamil, 2010) dapat dilihat pada gambar 1 dan bagan Model Pelukan HOTS bagi guru SD dapat dilihat pada gambar 2.

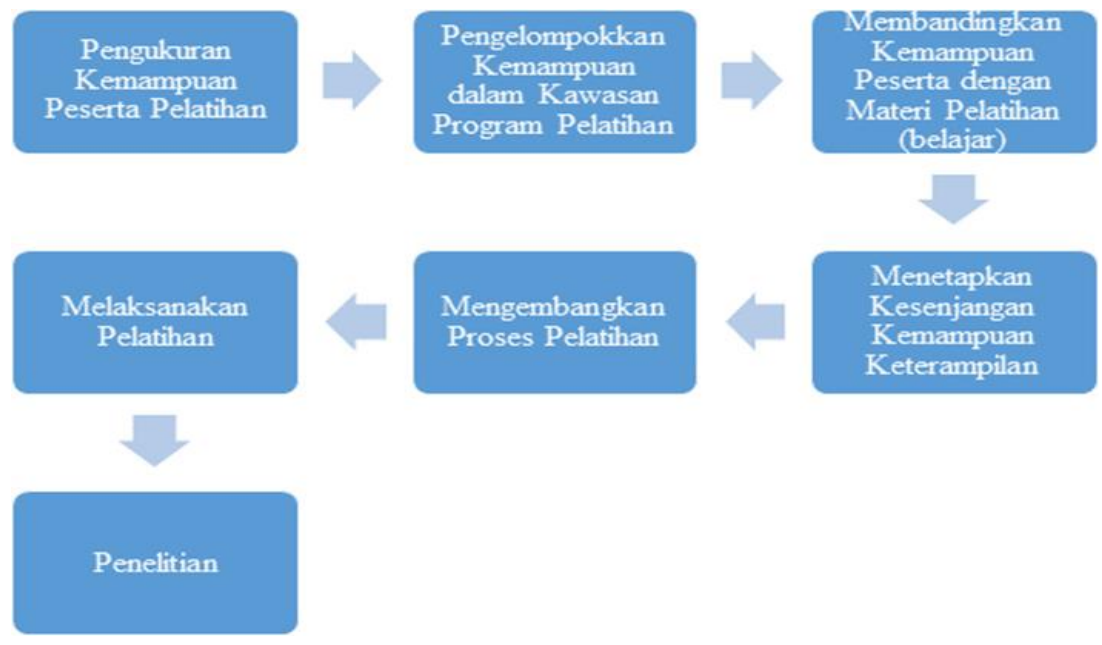

Gambar 1. Langkah-Langkah Model Pelatihan Induktif 


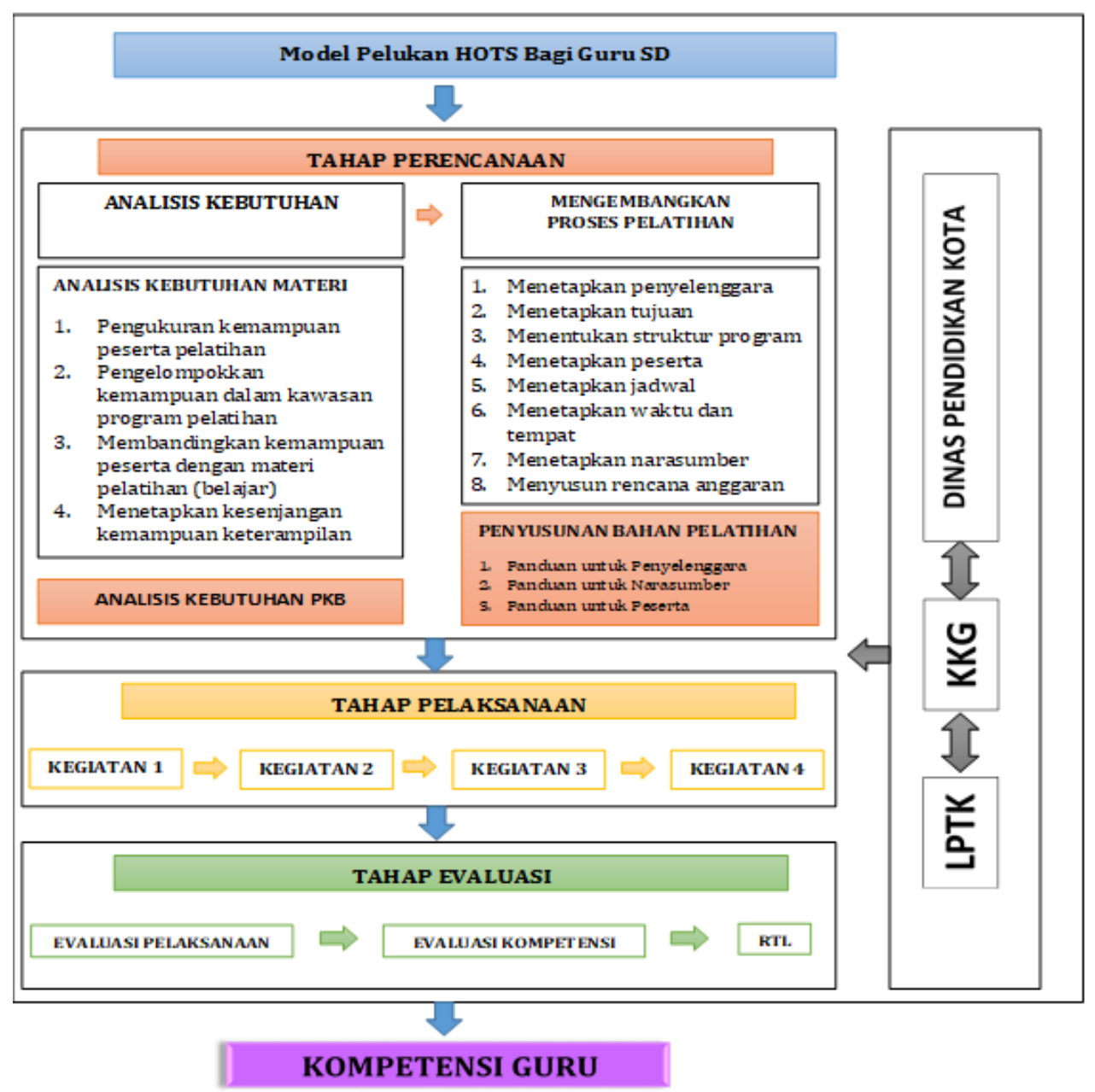

Gambar 2. Bagan Model Pelukan HOTS bagi Guru Sekolah Dasar

Tahap Perencanaan

Analisis Kebutuhan

Pada tahapan ini, dilakukan langkah pertama hingga keempat model pelatihan induktif guna menganalisis kebutuhan materi peserta pelatihan. Sebagai pengembangan dari model pelatihan induktif, pada tahap ini tak hanya menganalisis kebutuhan materi, tetapi juga kebutuhan pengembangan keprofesian berkelanjutan peserta pelatihan. Berikut adalah langkah menganalisis kebutuhan materi pelatihan (langkah 1-4 model pelatihan induktif), (1) pengukuran kemampuan peserta pelatihan. Peserta wajib mengumpulkan salah satu RPP yang telah digunakan dalam pembelajaran sebelum pelaksanaan pelatihan. RPP dianalisis oleh penyelenggara. Dalam menganalisis RPP dapat dilakukan sendiri atau bekerjasama dengan narasumber. Hasil analisis tersebut digunakan untuk mengukur kemampuan peserta pelatihan dalam menyusun RPP berorientasi HOTS, (2) pengelompokkan kemampuan dalam kawasan program pelatihan, (3) membandingkan kemampuan peserta dengan materi pelatihan (belajar), (4) menetapkan kesenjangan kemampuan keterampilan. Hasil analisis RPP kemudian juga dijadikan dasar untuk mengelompokkan kemampuan dalam kawasan program pelatihan. Dalam hal ini peserta pelatihan yang sudah baik dalam menyusun RPP berorientasi HOTS nantinya akan disebar ke dalam beberapa kelompok. Harapannya peserta-peserta tersebut dapat berperan sebagai tutor sebaya bagi guru-guru lain dalam kelompoknya untuk menyusun RPP berorientasi HOTS.

Selain analisis kebutuhan materi, dalam tahap ini peneliti menambahkan analisis kebutuhan PKB (Pengembangan Keprofesian Berkelanjutan). Sasaran pelatihan ini adalah guru SD yang juga berkewajiban melaksanakan kegiatan PKB. Sehingga penambahan analisis ini dipandang perlu untuk mengakomodasi kebutuhan peserta pelatihan. Analisis ini nantinya akan berpengaruh kepada struktur program pelatihan. 


\section{Mengembangkan Proses Pelatihan}

Pada tahap ini dilakukan langkah kelima model pelatihan induktif yakni mengembangkan proses pelatihan yang terdiri dari (1) menetapkan penyelenggara, penyelenggara yang dimaksud dalam model pelatihan ini adalah KKG (Kelompok Kerja Guru). Sebagaimana fungsinya, KKG adalah tempat untuk melakukan berbagai kegiatan penunjang kegiatan belajar mengajar, antara lain merencanakan strategi belajar mengajar, membuat alat pelajaran, membuat lembar kerja, Iembar tugas, dan mendiskusikan masalah-masalah yang dijumpai di kelas masing-masing guru. Sedangkan untuk susunan kepanitiaannya boleh diambil dari pengurus KKG atau dari anggota KKG yang bukan pengurus. Poin pentingnya adalah yang ditunjuk menjadi panitia penyelenggara pelatihan adalah orang-orang yang memenuhi persyaratan. Panitia Pelatihan Induktif Pembelajaran HOTS Bagi Guru SD terdiri dari: Ketua, Sekretaris, Bendahara, Sie Acara, Sie Konsumsi, Sie Humas, Sie Dokumentasi, dan Sie Perlengkapan, (2) menetapkan tujuan, (3) dari analisis kebutuhan materi ditetapkanlah tujuan pelatihan, (4) menentukan struktur program, (5) analisis kebutuhan materi dan analisis kebutuhan PKB menjadi dasar dalam menentukan struktur program kurikulum, (6) menetapkan peserta, (7) menetapkan jadwal, (8) menetapkan waktu dan tempat, (9) menetapkan narasumber, (10) menetapkan rencana anggaran, dan (11) menyusun panduan pelatihan. Adapun panduan yang disusun adalah panduan penyelenggara, panduan narasumber, dan panduan peserta.

\section{Tahap Pelaksanaan}

Pelaksanaan kegiatan Pelatihan Induktif Pembelajaran HOTS Bagi Guru SD dijadwalkan selama empat hari. Masingmasing hari terdiri dari 8 JP sehingga total kegiatan adalah 32 JP, 1 JP setara 45 menit. Pelaksanaan dapat dilaksanakan secara luring atau daring dapat dilihat pada tabel 1.

Tabel 1. Pelaksanaan Kegiatan Pelatihan Induktif Pembelajaran HOTS Bagi Guru SD

\begin{tabular}{|c|c|c|}
\hline No. & Materi & Alokasi Waktu (JP) \\
\hline 1. & Kebijakan Dinas & $2 \mathrm{JP}$ \\
\hline 2. & Peran Guru dalam Melaksanakan Kebijakan-kebijakan Pendidikan & $2 \mathrm{JP}$ \\
\hline 3. & Pengembangan Pembelajaran Berorientasi HOTS & $6 \mathrm{JP}$ \\
\hline 4. & Teori Pengembangan RPP dan Penilaian HOTS & $4 \mathrm{JP}$ \\
\hline 5. & Rambu-rambu Implementasi Penyusunan RPP dan Penilaian HOTS & $4 \mathrm{JP}$ \\
\hline 6. & Praktik Penyusunan RPP Berorientasi HOTS & $12 \mathrm{JP}$ \\
\hline 7. & Penyusunan Laporan Pengembangan Diri & $2 \mathrm{JP}$ \\
\hline & Total & $32 \mathrm{JP}$ \\
\hline
\end{tabular}

\section{Tahap Evaluasi}

Berikut ini adalah tahapan evaluasi (1) evaluasi pelaksanaan. Penyelenggara melakukan evaluasi jalannya proses pelatihan dengan melakukan observasi terhadap jalannya pelatihan. Observasi ini dapat dilakukan langsung selama pelatihan berlangsung. Observasi juga dapat dilakukan secara tak langsung dengan melihat video rekaman jalannya pelatihan; (2) evaluasi kompetensi. Evaluasi kompetensi dilakukan dengan menganalisis perbandingan penilaian RPP peserta sebelum pelatihan dan sesudah pelatihan. Evaluasi kompetensi dapat dilakukan penyelenggara pelatihan bekerja sama dengan narasumber. Adapun instrumen yang digunakan untuk menganalisis RPP peserta pelatihan diambil dari Instrumen Penilaian RPP PPG Dalam Jabatan FKIP PGSD Universitas Kristen Satya Wacana 2020; (3) RTL (Rencana Tindak Lanjut) dalam hal ini dibedakan menjadi tiga, yakni (a) penyelenggara: Membuat laporan kegiatan baik untuk Dinas Pendidikan dan untuk LPTK (bila bekerja sama dengan LPTK). Laporan ini dibuat untuk mendapatkan sertifikat pelatihan. Sertifikat pelatihan bagi peserta maupun bagi narasumber, (b) narasumber: Menilai tugas peserta pelatihan. Tugas yang dinilai dalam hal ini adalah produk RPP peserta. Nilai tersebut kemudian dibandingkan dengan penilaian RPP sebelum pelatihan. Kemudian hasilnya dianalisis, untuk mengetahui keefektifan pelatihan, (c) peserta: Menyusun kelengkapan perangkat pembelajaran sesuai dengan RPP yang berhasil disusun. Kemudian mengimplementasikan RPP tersebut dalam pembelajaran. Selain itu, juga menyusun laporan pengembangan diri, untuk selanjutnya diverifikasi oleh koordinator PKB dan disahkan kepala sekolah masing-masing. Setelah disahkan dapat diusulkan untuk kenaikan pangkat.

Keunggulan dari model pelatihan yang dikembangkan ini bila dibandingkan dengan model pelatihan yang sudah ada, yaitu (1) memberikan pemahaman yang utuh kepada peserta terkait HOTS, tidak seperti pelatihan yang terselenggara selama ini yang hanya fokus pada penyusunan soal HOTS; (2) produk yang berupa panduan peserta, selain menyajikan materi pelatihan juga dilengkapi format pembuatan laporan pengembangan diri untuk kepentingan Penilaian Angka Kredit (PAK). Jadi, selain memenuhi kebutuhan peserta dari sisi materi juga memenuhi kebutuhan peserta dari sisi PKB untuk kepentingan PAK; (3) sinergi yang terbangun antara KKG, Dinas Pendidikan, dan LPTK yang saling menguntungkan. 


\section{PEMBAHASAN}

Diintegrasikannya soal HOTS dalam evaluasi pembelajaran seharusnya diawali dengan pembelajaran berorientasi HOTS. Kesenjangan tidak dapat dihindari ketika penilaiannya sudah berorientasi HOTS, namun pembelajarannya belum berorientasi HOTS. Kesenjangan tersebut berdampak terhadap hasil evaluasi pembelajaran peserta didik. Kompetensi guru dalam merancang dan mengimplementasikan pembelajaran berorientasi HOTS perlu ditingkatkan untuk meningkatkan kualitas pembelajaran. Salah satu upaya untuk meningkatkan kompetensi guru melalui pelatihan. Hal ini sejalan dengan pendapat (Zainal et al., 2019) pelatihan memiliki orientasi kondisi terkini untuk memberi bantuan pegawai untuk mencapai kompetensi dan keterampilan tertentu supaya berhasil melaksanakan pekerjaan. Pegawai yang dimaksud dalam hal ini adalah guru, sedangkan kompetensi dan keterampilan tertentu yang dimaksud adalah menyusun RPP berorientasi HOTS.

Hasil dari penelitian menunjukkan bahwa pelatihan tentang HOTS yang terselenggara selama ini hanya fokus pada penyusunan soal HOTS, itupun hanya menjadi bagian dari sub materi dari sebuah pelatihan. Padahal pelatihan tentang HOTS mulai dari bagaimana mendesain pembelajaran, penilaian hingga penyusunan RPP berorientasi HOTS sangat dibutuhkan guru. Hal tersebut seiring dengan (Noe et al., 2010) yang berpendapat bahwa pelatihan bagi guru adalah sarana untuk meningkatkan kompetensi sikap, pengetahuan, dan keterampilan dalam tugas pokok dan fungsinya. Jadi, ketika sebuah pelatihan tidak menjawab apa yang menjadi kebutuhan guru, maka fungsi dari pelatihan tersebut kurang bermanfaat secara nyata dalam meningkatkan kompetensi guru.

Kelemahan dari pelatihan sebelumnya selain masih berfokus pada penilaian HOTS saja, kuota peserta terbatas, peserta yang mewakili sekolah tidak menjalankan diseminasinya dengan baik, alokasi waktu pelatihan terbatas, struktur program pelatihan belum setara $30 \mathrm{JP}$ syarat minimal untuk mendapatkan poin pengembangan diri pada pengajuan PAK. Kelemahankelemahan di atas tidak sejalan dengan tujuan pelatihan itu sendiri, seperti yang diungkapkan Sugandhi (2016) dimana pelatihan haruslah menjadi sarana pemenuhan kebutuhan peserta pelatihan untuk dapat mengembangkan keterampilan, pengetahuan, sikap yang dapat dimanfaatkan oleh peserta pelatihan setelah mengikuti pelatihan tersebut sesuai dengan kompetensinya sebagai upaya pengembangan diri. Lebih lanjut, Sugandhi (2016) mengungkapkan bahwa tujuan pelatihan antara lain untuk memecahkan permasalahan operasional dan mempersiapkan karyawan untuk promosi. Dalam hal ini permasalahan yang dihadapi guru adalah tentang bagaimana menyusun RPP HOTS yang dapat diimplementasikan dalam pembelajaran. Berkaitan dengan mempersiapkan karyawan untuk promosi yang dimaksud adalah guru sebagai peserta pelatihan juga membutuhkan pelatihan yang struktur programnya dapat memenuhi kebutuhan mereka untuk pengembangan diri sebagai salah satu syarat kenaikan pangkat. Berdasarkan hal-hal di atas maka model pelatihan yang paling tepat adalah model pelatihan induktif. Model pelatihan induktif adalah model prosedural yang menitikberatkan pada pemenuhan kebutuhan peserta pelatihan (Kamil, 2010).

Tahapan penelitian pengembangan hingga menghasilkan sebuah produk ini merujuk pada tahapan penelitian pengembangan (Sugiyono, 2010). Pada penelitian ini peneliti membatasi sampai tahap ketujuh. Tahapan tersebut, meliputi (1) potensi dan masalah; (2) pengumpulan data; (3) desain produk; (4) validasi desain; (5) revisi desain; (6) ujicoba produk; (7) revisi produk, dimana tahapan-tahapan tersebut berhasil menciptakan sebuah produk model pelatihan.

Potensi dan masalah yang terungkap dalam hasil penelitian adalah sebagian besar guru SD di lingkungan Kecamatan Sidomukti memiliki latar belakang pendidikan yang linier, yakni S1 PGSD dan sebagian besar sudah menyandang gelar guru profesional. Di Kecamatan Sidomukti ada tiga KKG sebagai wadah untuk pengembangan diri guru. Masalah yang ada selama ini khususnya terkait pelatihan yang diadakan dengan topik HOTS belum sesuai kebutuhan guru baik dari sisi materi, narasumber, alokasi waktu, struktur program, sehingga kompetensi guru dalam menyusun RPP HOTS masih rendah. Kompetensi guru yang masih rendah tersebut menyebabkan guru kesulitan dalam menerapkan pembelajaran HOTS di kelas. Selain itu, kebutuhan untuk kegiatan PKB yang mengarah pada PAK juga belum terpenuhi secara maksimal. Kebutuhan guru dan masalah yang dihadapi guru tersebut menjadi dasar untuk mengembangkan model pelatihan. Sejalan dengan hasil tersebut Kamil (2010) menyatakan untuk menyusun suatu materi atau modul pelatihan sangat diperlukan identifikasi kebutuhan dan kemampuan sehingga materi yang dibuat lebih efektif.

Hasil pengumpulan data awal menunjukkan bahwa guru masih mengalami kesulitan dalam menerapkan pembelajaran HOTS dikarenakan belum memahami betul apa itu HOTS, juga belum adanya pelatihan terkait HOTS yang sesuai kebutuhan guru, baik dari sajian materi maupun struktur program yang dapat mengakomodasi kebutuhan unsur pengembangan diri dalam PKB. Model pelatihan yang dikembangkan merupakan model prosedural, dimana terdapat langkah-langkah melaksanakan pelatihan sehingga tujuan pelatihan dapat tercapai. Model Pelukan HOTS bagi guru SD ini adalah model yang dikembangkan dengan menitikberatkan usaha untuk menjawab kebutuhan peserta pelatihan baik dari segi materi maupun pemenuhan kebutuhan pengembangan diri untuk pengajuan PAK. Model pelatihan dikembangkan berdasarkan model pelatihan induktif (Kamil, 2010).

Keunggulan model pelatihan yang dikembangkan dibandingkan dengan yang pernah ada adalah selain dari segi materi dan pemenuhan kebutuhan pengembangan diri untuk pengajuan PAK adalah sinergi antara KKG, Dinas Pendidikan, dan LPTK. Bagi KKG, terfasilitasinya pemenuhan peserta akan sertifikat yang dapat digunakan untuk kebutuhan PAK dengan persetujuan pengajuan proposal pelatihan ke Dinas Pendidikan. Dinas Pendidikan terbantu oleh KKG khususnya dalam menjangkau lebih banyak guru yang mendapatkan pelatihan pembelajaran HOTS. Bagi LPTK, terpenuhinya salah satu fungsi Tridarma, yaitu pengabdian masyarakat dengan mengirim dosen-dosen menjadi narasumber. Dosen-dosen yang berpartisipasi menjadi narasumber juga akan mendapat poin untuk jenjang karirnya. Adanya kerja sama dengan LPTK melalui program pengabdian 
masyarakat, selain terpenuhinya kebutuhan akan narasumber yang kompeten, biaya pelatihan juga akan berkurang karena tidak perlu mengeluarkan biaya bagi narasumber yang berasal dari LPTK. Hal ini sesuai yang dinyatakan Moekijat (2011), pelatihan dapat mengembangkan sikap supaya terwujud sinergi antar pihak terkait kegiatan pelatihan.

Tahap desain produk pada model pelatihan meliputi: Bagian Awal, Pendahuluan, Kajian teori, Model Pelatihan Induktif Pembelajaran HOTS Bagi Guru SD, Prasyarat Keefektifan Model, Penutup, Daftar Pustaka, Glosarium, dan Lampiran. Bagian Awal, meliputi Kata Pengantar dan Daftar Isi. Pendahuluan meliputi: Latar Belakang, Dasar Hukum, Tujuan, Manfaat, Sasaran, dan Target Kompetensi. Kajian Teori terdiri dari: Pelatihan (pengertian, tujuan, manajemen, model, jenis, dan model pelatihan induktif), Kompetensi Guru, Pembelajaran HOTS, dan Pengembangan Model Pelatihan. Bab selanjutnya membahas Model Pelatihan Induktif Pembelajaran HOTS bagi guru SD menjabarkan tentang rasional model, spesifikasi model, bagan model, dan deskripsi model. Bab berikutnya menjelaskan Prasyarat Keefektifan Model. Bagian penutup menyajikan harapan dan capaian dari pengembangan model pelatihan yang efektif. Daftar pustaka berisi referensi-referensi yang digunakan sebagai rujukan dalam penyusunan model. Glosarium berisi tentang arti kata-kata sulit yang terdapat pada model. Lampiran-lampiran yang terdiri dari (1) panduan penyelenggara, (2) panduan narasumber, dan (3) panduan peserta. Panduan-panduan tersebut dibuat sebagai acuan dengan tujuan memudahkan bagi pihak-pihak terkait dalam melaksanakan pelatihan (Tabel 2). Jika disandingkan dengan perhitungan skor untuk mengetahui kriteria pengembangan model beserta panduannya yang ditentukan dengan rumus dapat dilihat pada tabel 3.

Tabel 2. Rekapitulasi Skor dan Kriteria Model Beserta Panduan Pelatihan

\begin{tabular}{|c|c|c|c|c|c|}
\hline \multirow{2}{*}{ No. } & \multirow{2}{*}{ Validator Ahli } & \multicolumn{4}{|c|}{ Rata-rata Skor } \\
\hline & & Model & Panduan Penyelenggara & Panduan Narasumber & Panduan Peserta \\
\hline \multirow[t]{2}{*}{1} & Dr. Mawardi, M.Pd. & 120 & 61 & 58 & 69 \\
\hline & & (SB) & (SB) & (SB) & $(\mathrm{SB})$ \\
\hline \multirow[t]{2}{*}{2} & Dr. Ade Iriani, M.M & 101 & 52 & 49 & 58 \\
\hline & & (B) & (SB) & (SB) & (B) \\
\hline \multirow[t]{5}{*}{3} & Niek Setya Handayani, S.Pd. & 127 & 58 & 55 & 69 \\
\hline & & (SB) & (SB) & (SB) & $(\mathrm{SB})$ \\
\hline & Jumlah skor & 348 & 171 & 162 & 196 \\
\hline & Rata-rata skor & 116 & 57 & 54 & 65 \\
\hline & Kriteria & SB & SB & SB & SB \\
\hline
\end{tabular}

Keterangan: SB (Sangat Baik), B (Baik)

Tabel 3. Perhitungan Skor Kriteria Pengembangan Model

\begin{tabular}{cl}
\hline \multicolumn{1}{c}{ Skor } & Kualifikasi \\
\hline Q3 $\leq$ skor $\leq$ T & Baik Sekali \\
Q2 $\leq$ skor $\leq$ Q3 & Baik \\
Q1 $\leq$ skor $\leq$ Q2 & Cukup \\
R $\leq$ skor $\leq$ Q1 & Kurang \\
\hline
\end{tabular}

Hasil validasi desain oleh ahli menunjukkan kriteria sangat baik. Kriteria tersebut tidak hanya untuk model pelatihan, namun juga untuk panduan penyelenggara, panduan narasumber, dan panduan peserta. Hal tersebut bermakna bahwa secara keseluruhan menyatakan pengembangan model pelatihan yang telah didesain dapat diujicobakan. Sebelum diujicobakan, peneliti merevisi model sesuai dengan saran masukan dari validator ahli. Tahapan revisi desain ini dimaksudkan untuk mempersiapkan model pelatihan hingga benar-benar siap diujicobakan. Peneliti juga melakukan FGD yang diikuti oleh tujuh orang yang terdiri dari tiga orang pengurus KKG Gajah Mada, tiga orang pengurus K3S Gugus Gajah Mada, satu anggota KKG Gugus Gajah Mada. Ujicoba produk nantinya akan dilaksanakan dengan memperhatikan hasil FGD hal ini sesuai saran yang dikemukakan oleh (Kamil, 2010) peneliti diharapkan mencermati notula atau rekaman hasil FGD untuk menentukan langkah selanjutnya. Berbagai persiapan dilakukan peneliti untuk memastikan ujicoba berjalan sebagaimana yang diharapkan. Persiapan tersebut, meliputi (1) mengurus perizinan pelaksanaan di KKG Gugus Gajah Mada; (2) penyusunan proposal ke Dinas Pendidikan dan Progdi PGSD FKIP UKSW; (3) persiapan tempat dan platform yang digunakan hingga infografis kegiatan. Persiapan yang dilakukan termasuk pembuatan instrumen lembar observasi pelaksanaan pelatihan dan menghubungi kesediaan observer yang akan mengamati jalannnya pelatihan.

Ujicoba produk menunjukkan keefektifan model pelatihan, hal ini dapat dilihat dari peserta pelatihan secara umum memperoleh kemampuan untuk menyusun RPP berorientasi HOTS, terlihat dari RPP yang berhasil disusun dari pelatihan. Jika dibandingkan dengan RPP yang dikumpulkan peserta sebelum pelatihan. RPP hasil pelatihan yang penyusunannya dibimbing dosen-dosen Prodi PGSD FKIP UKSW dalam kelompok-kelompok menunjukkan perbaikan yang dapat dilihat pada tabel 4. Strategi bimbingan kelompok ini sejalan dengan penelitian yang dilakukan oleh Santosa (2020) yang berjudul Improving Teacher's Ability to Make Lesson Plan Based on High Order Thinking Skills (HOTS) Through Group Guidance. Berdasarkan 
hasil penelitian dapat disimpulkan bahwa kemampuan guru SMPN 2 Cerenti dalam menyusun RPP berbasis HOTS mengalami peningkatan melalui bimbingan kelompok.

Tabel 4. Rekapitulasi Perbandingan RPP Sebelum dan Sesudah Pelatihan

\begin{tabular}{|c|c|c|c|}
\hline No. & Komponen RPP & $\begin{array}{c}\text { RPP } \\
\text { Sebelum Pelatihan } \\
\end{array}$ & $\begin{array}{c}\text { RPP } \\
\text { Setelah Pelatihan } \\
\end{array}$ \\
\hline 1. & Tujuan Pembelajaran & $\begin{array}{l}\text { Kata kerja operasional yang digunakan dapat } \\
\text { diamati diamati dan diukur } \\
\text { Tujuan pembelajaran sudah menunjukkan HOTS } \\
\text { dalam rumusan ranah pengetahuan } \\
\text { Rumusannya sudah mencakup ABCD }\end{array}$ & $\begin{array}{l}\text { Kata kerja operasional yang digunakan dapat } \\
\text { diamati dan diukur } \\
\text { Tujuan pembelajaran sudah menunjukkan HOTS } \\
\text { dalam rumusan ranah pengetahuan } \\
\text { Rumusannya sudah mencakup ABCD }\end{array}$ \\
\hline 2. & $\begin{array}{l}\text { Langkah-langkah/ } \\
\text { Sintak Pembelajaran }\end{array}$ & $\begin{array}{l}\text { Tidak sesuai dengan langkah-langkah sintak } \\
\text { pembelajaran } \\
\text { Tahapan kegiatan sudah mencakup tahapan } \\
\text { pendahuluan, inti, penutup diertai alokasi waktu di } \\
\text { setiap tahapan } \\
\text { Langkah-langkah pembelajaran masih ada yang } \\
\text { belum mencerminkan pembelajaran aktif/saintifik } \\
\text { Sumber belajar masih ada yang belum berbasis } \\
\text { ICT }\end{array}$ & $\begin{array}{l}\text { Sesuai dengan langkah-langkah sintak } \\
\text { pembelajaran } \\
\text { Tahapan kegiatan sudah mencakup tahapan } \\
\text { pendahuluan, inti, penutup diertai alokasi waktu di } \\
\text { setiap tahapan } \\
\text { Langkah-langkah pembelajaran sudah } \\
\text { mencerminkan pembelajaran aktif/saintifik } \\
\text { Sumber belajar sudah berbasis ICT }\end{array}$ \\
\hline 3. & Evaluasi & $\begin{array}{l}\text { Cakupan aspek penilaian hanya mencakup satu } \\
\text { aspek } \\
\text { Evaluasi tidak sesuai dengan tujuan/indikator dan } \\
\text { orientasi HOTS baik luring maupun draing } \\
\text { Komponen penilaian tidak lengkap hanya terdiri } \\
\text { atas tes/soal } \\
\text { Tidak merencanakan kegiatan pengayaan/remedial }\end{array}$ & $\begin{array}{l}\text { Cakupan aspek penilaian mencakup sikap, } \\
\text { pengetahuan, dan keterampilan } \\
\text { Evaluasi sesuai dengan tujuan/indikator dan } \\
\text { orientasi HOTS baik luring maupun draing } \\
\text { Komponen penilaian lengkap } \\
\text { Tidak merencanakan kegiatan pengayaan/remedial }\end{array}$ \\
\hline
\end{tabular}

Perbaikan RPP utamanya dalam komponen-komponen terkait HOTS, baik dalam perumusan tujuan pembelajaran, langkah-langkah pembelajaran, dan evaluasi. Hal tersebut menunjukkan pengembangan model pelatihan dapat meningkatkan kompetensi guru dalam menyusun RPP berorientasi HOTS. Hasil penelitian tersebut sejalan dengan penelitian (Alghamdi, 2018) menyatakan sebanyak $89 \%$ peserta bersemangat untuk menerapkan pengetahuan dan skill untuk mengerjakan segala tugas dalam pelatihan HOTS. Selain itu, semua peserta pelatihan telah memahami konsep dasar HOTS dan mampu menerapkan secara mendalam dalam proses belajar mengajar. Lebih lanjut, hasil implementasi model pelatihan yang dikembangkan juga sejalan dengan (Rahaju \& Fardah, 2018) menyatakan bahwa melalui pelatihan HOTS sebanyak enambelas guru mampu menyusun soal HOTS, dan hanya satu guru yang masih belum mampu menyusun soal HOTS di akhir pelatihan.

Selain itu, jika dilihat dari segi pelaksanaan, hasil observasi menunjukkan pelaksanaan pelatihan termasuk kriteria baik. Sembilan dari 10 komponen dinilai representatif oleh lima observer, hanya satu komponen yang menjadi kendala pada pelaksanaan pelatihan. Satu komponen tersebut adalah faktor jaringan yang membuat komponen platform yang digunakan dalam pelatihan kurang maksimal. Pelatihan dilaksanakan secara daring selama empat hari dikarenakan Kota Salatiga masih berada pada zona orange terkait pandemi Covid-19. Berdasarkan tabel 5, dapat diketahui bahwa rata-rata hasil observasi jalannya pelaksanaan ujicoba pelatihan berada pada kategori baik $(30,75)$ dengan perhitungan rentang nilai quartil pada tabel 6 .

Tabel 5. Rekapitulasi Hasi Observasi

\begin{tabular}{ccccc}
\hline $\begin{array}{c}\text { Hari } \\
\text { Observer }\end{array}$ & H1 & H2 & H3 & H4 \\
\hline Observer 1 & 34 & 33 & 31 & 27 \\
Observer 2 & 22 & 20 & 20 & 20 \\
Observer 3 & 35 & 30 & 31 & 31 \\
Observer 4 & 38 & 34 & 33 & 32 \\
Observer 5 & 37 & 36 & 36 & 35 \\
Jumlah & 166 & 153 & 151 & 145 \\
\hline Rata-rata & \multicolumn{4}{c}{30,75 (Baik) } \\
\hline
\end{tabular}




\section{Tabel 6. Rata-Rata Hasil Observasi}

\begin{tabular}{cc}
\hline Skor & Kriteria \\
\hline $33-40$ & Baik sekali \\
$25-32$ & Baik \\
$18-24$ & Cukup \\
$10-17$ & Kurang \\
\hline
\end{tabular}

Setelah diujicobakan pengembangan model pelatihan yang dikembangkan berdasarkan model pelatihan induktif di mana kebutuhan peserta pelatihan menjadi hal yang diprioritaskan berjalan dengan baik dan mampu meningkatkan kompetensi guru dalam menyusun RPP HOTS. Hal ini sejalan dengan penelitian yang dilakukan oleh Gunarso \& Sulasmono (2015) dengan penelitiannya yang berjudul Pengembangan Model Diklat Guru Sosiologi SMA tentang Pembelajaran Inkuiri Berbasis Budaya Lokal. Riyanti (2018) dengan penelitiannya yang berjudul Pengembangan Model Pelatihan Guru PPKn Berwawasan Pluralisme, keduanya sama-sama mengembangkan model pelatihan induktif dan hasil dari kedua penelitian tersebut mengungkapkan keefektifan model pelatihan induktif dalam meningkatkan kompetensi guru. Berdasarkan hasil ujicoba yang menunjukkan keefektifan modul, ditambah lagi dengan revisi setelah tahapan ujicoba produk menunjukkan model pelatihan ini layak digunakan untuk pelatihan berikutnya. Hal ini sejurus dengan pernyataan Sugiyono (2010) produk yang sudah diujikan pada tahap 6 ujicoba produk dan direvisi pada tahap 7 lebih optimal jika digunakan untuk tahapan selanjutnya.

\section{SIMPULAN}

Pelatihan pembelajaran HOTS yang diselenggarakan di Kecamatan Sidomukti hanya berfokus pada penyusunan soal HOTS. Kelemahan pelatihan pembelajaran HOTS di Kecamatan Sidomukti belum menjawab kebutuhan guru SD baik dari segi materi maupun segi pengembangan diri. Sementara itu, kelebihannya semua SD baik negeri maupun swasta, sudah ada perwakilan guru yang mendapatkan pelatihan dengan topik HOTS. Terciptanya Model Pelukan HOTS bagi guru SD yang memiliki keunggulan dibandingkan dengan model pelatihan yang sudah ada dalam hal kelengkapan materi, pemenuhan kebutuhan peserta dari sisi PKB untuk kepentingan PAK, dan sinergi saling menguntungkan yang terbangun antara KKG, Dinas Pendidikan, dan LPTK. Produk model pelatihan yang dikembangkan masuk pada kriteria sangat baik setelah divalidasi oleh tiga pakar. Hasil ujicoba produk juga berada pada kategori baik.

\section{DAFTAR RUJUKAN}

Alghamdi, A. K. H. (2018). Faculty Professional Development and its Impact on Teaching Strategies in Saudi Arabia. Journal of Teaching and Teacher Education, 6(02), 77-93.

Arnellis, A., Jamaan, E. Z., \& Amalita, N. (2019). Improving Teacher Professionalism Through In-House Training Model to Higher Order Thinking Skills Items SMAN 10 Reference Padang. Pelita Eksakta, 2(1), 74-78.

Effendi, E., \& Gunarto, W. (2019). Pelatihan pembelajaran dan penilaian berbasis HOTS (Higher Order Thingking Skill) bagi guru SD. Jurnal Indonesia Mengabdi, 1(2), 40-43.

Faisal, F., Mailani, E., Ananda, L. J., \& Lova, S. M. (2019). Deskripsi Implementasi Penilaian Autentik Berbasis High Order Thinking Skills (HOTS) dalam Menjawab Tantangan Abad 21 di Sekolah Dasar Kota Medan. Elementary School Journal PGSD FIP Unimed, 9(2), 126-132.

Febrianti, V. (2017). Peranan Guru dalam Pengembangan Instrumen Penilaian High Order Thinking Skill pada Mata Pelajaran PPKn untuk Siswa Kelas XI SMA di Kabupaten Sleman. Jurnal Jurnal Pendidikan Kewaraganegaraan dan Hukum, 2(1), 9-18.

Gunarso, G., \& Sulasmono, B. S. (2015). Pengembangan Model Diklat Guru Sosiologi SMA tentang Pembelajaran Inkuiri Berbasis Budaya Lokal. Kelola: Jurnal Manajemen Pendidikan, 2(1), 34-46.

Hanifah, N. (2019). Pengembangan Instrumen Penilaian Higher Order Thinking Skill (HOTS) di Sekolah Dasar. Current Research in Education: Conference Series Journal, 1(1), 5.

Hepp, P., Fernández, M. À. P., \& García, J. H. (2015). Teacher Training: Technology Helping to Develop an Innovative and Reflective Professional Profile. International Journal of Educational Technology in Higher Education, 12(2), 30-43.

Hidayat, A., \& Mariam, P. (2018). Pengembangan Kemampuan Menulis Penelitian Tindakan Kelas Guru MTs. Miftahulfalah Bandung. Educare, 16(2), 1-7.

Kamil, M. (2010). Model Pendidikan dan Pelatihan (Konsep dan Aplikasi). Bandung: Alfabeta.

Kuncoro, T. A. (2018). Peningkatan Kinerja Guru Penjasorkes melalui Pendidikan dan Latihan Model Induktif Perangkat Kurikulum di UPTD Pendidikan Kecamatan Tugu dan Kecamatan Ngaliyan Kota Semarang. Universitas Kristen Satya Wacana.

Mailani, E. (2018). Potret Implementasi Pembelajaran Berbasis High Order Thinking Skills (HOTS) di Sekolah Dasar Kota Medan. Jurnal Pembangunan Perkotaan, 6(2), 102-111.

Mikidadi, M. M. (2013). The Effectiveness of Training of Government Primary School Teachers on Job Performance: The Case of Bukoba District Council. The Open University of Tanzania. 
Moekijat, M. (2011). Latihan dan Pengembangan Sumber Daya Manusia. Bandar Maju.

Noe, R. A., Hollenbeck, J. R., Gerhart, B., \& Wright, P. M. (2010). Manajemen Sumber Daya Manusia Mencapai Keunggulan Bersaing. In Human Resources Management: Gaining a Competitive Advantage. McGraw-Hill/Irwin Boston, MA.

Rahaju, E. B., \& Fardah, D. K. (2018). An Identification of Teachers' Ability on Posing HOTS Mathematics Problems. International Conference on Science and Technology (ICST 2018).

Rapih, S., \& Sutaryadi, S. (2018). Perpektif Guru Sekolah Dasar terhadap Higher Order Tinking Skills (HOTS): Pemahaman, Penerapan dan Hambatan. Premiere Educandum: Jurnal Pendidikan Dasar dan Pembelajaran, 8(1), $78-87$.

Riyanti, E. (2018). Pengembangan Model Pelatihan Guru PPKn Berwawasan Pluralisme. Universitas Kristen Satya Wacana.

Samo, D. D., \& Garak, S. S. (2019). Pelatihan Pengembangan Soal Geometri Level Higher-Order Thinking Skill (HOTS) bagi guru Sekolah Dasar di Kota Kupang. Jurnal Pengabdian Masyarakat Ilmu Keguruan dan Pendidikan (JPM-IKP), 2(01), 17-27.

Santosa, E. R. (2020). Improving Teacher's Ability to Make Lesson Plan Based on High Order Thinking Skills (HOTS) through group guidance. Jurnal Pajar (Pendidikan Dan Pengajaran), 4(2), 338-346.

Setiawan, A. M., Munzil, M., Sugiyanto, S., Muhardjito, M., Pratiwi, N., Yulianti, E., \& Marsuki, M. F. (2019). Workshop Pengembangan Soal-Soal HOTS (High Order Thinking Skills) bagi MGMP IPA SMP Banyuwangi. Jurnal Pembelajaran Sains, 3(1), 21-23.

Sugandhi, D. F. P. (2016). Pemanfaatan Hasil Belajar pada Pelatihan Keterampilan Mekanik Otomotif: Studi Kasus pada Lulusan Lembaga Pendidikan Keterampilan Pelita Massa. Universitas Pendidikan Indonesia.

Sugiyono, P. D. (2010). Metode Penelitian Pendidikan Pendekatan Kuantitatif, Kualitatif, dan R \& D. Bandung: Alfabeta.

Suhardiyanto, A., \& Tijan, T. (2019). Pendampingan Pengembangan Penilaian Pengetahuan Berbasis HOTS bagi MGMP PPKn SMP di Kota Semarang. Jurnal Panjar: Pengabdian Bidang Pembelajaran, 1(1), 65-69.

Supriyadi, S., Rusilowati, A., Isnaeni, W., \& Winarsih, R. (2019). Peningkatan Kemampuan Guru SD di Kecamatan Gajah Mungkur dalam Menyusun Soal HOTS Setelah Mengikuti Pelatihan. Prosiding Seminar Nasional Pascasarjana (Prosnampas), 2(1), 844-848.

Ulla, M. B., Barrera, K. I. B., \& Acompanado, M. M. (2017). Philippine Classroom Teachers as Researchers: Teachers' Perceptions, Motivations, and Challenges. Australian Journal of Teacher Education, 42(11), 4.

Wardhana, D. E. C., Ariesta, R., \& Sarwono, S. (2020). Pelatihan Penyusunan Soal Bahasa Indonesia Berorientasi HOTS untuk Guru SMP dan SMA. ABDI: Jurnal Pengabdian dan Pemberdayaan Masyarakat, 2(1), 1-11.

Zainal, V. R., Ramly, H. M., Mutis, T., \& Arafah, W. (2019). Manajemen Sumber Daya Manusia untuk Perusahaan dari Teori ke Praktik. Jakarta: Raja Grafindo Persada.

Zarkasi, A. (2019). Peningkatan Keterampilan Guru Dalam Penyusunan RPP berbasis HOTS melalui Workshop dan Pembimbingan di SMA Negeri 8 Penajam Paser Utara. Kompetensi, 12(1), 86-96. 